\title{
Detection of Clostridium botulinum group III in environmental samples from farms by real-time PCR using four commercial DNA extraction kits
}

\author{
Caroline Le Maréchal ${ }^{1 *}$, Sarah Fourour ${ }^{1}$, Valentine Ballan ${ }^{1}$, Sandra Rouxel ${ }^{1}$, Rozenn Souillard ${ }^{2}$ \\ and Marianne Chemaly ${ }^{1}$
}

\begin{abstract}
Objectives: Few studies have tested DNA extraction methods to optimize the detection of Clostridium botulinum in environmental samples that can be collected during animal botulism outbreaks. In this study, we evaluated four commercial DNA extraction kits for the detection of C. botulinum group III in 82 various environmental samples (9 manure, 53 swabs, 3 insects, 8 water, 1 silage and 8 soil samples) collected in a context of animal botulism outbreaks.

Results: The PowerSoil ${ }^{\circledR}$ kit was the most efficient for almost all matrices (83.6\% of the 73 tested samples), except manure for which the NucleoSpin ${ }^{\circledR}$ Soil kit was the most efficient. The NucleoSpin ${ }^{\circledR}$ Soil kit enabled detection in 75.3\%, the QIAamp ${ }^{\circledR}$ DNA Mini Kit in 68.5\%, and the QIAamp ${ }^{\circledR}$ Fast DNA Stool Mini Kit in 45.2\%. However, the NucleoSpin ${ }^{\circledR}$ Soil kit detected C. botulinum in 9 of the 9 manure samples tested, while the PowerSoil ${ }^{\circledR}$ kit found C. botulinum in only two samples, and the other two kits in none of the samples. This study showed that PowerSoil ${ }^{\circledR}$ can be recommended for DNA extraction from environmental samples except for manure, for which the NucleoSpin ${ }^{\circledR}$ Soil kit appeared to be far more appropriate.
\end{abstract}

Keywords: Clostridium botulinum, DNA extraction, Real-time PCR, Detection, Freezing

\section{Introduction}

Animal botulism has increased for the last decade in Europe [1]. In France, 129 outbreaks of botulism in wild birds and 396 in poultry between 2000 and 2013 have been recorded [2]. Botulism is a paralytic disease due to the action of botulinum neurotoxin (BoNT). C. botulinum strains are divided into four groups based on their physiological traits and the toxins they produce. Strains belonging to C. botulinum group III produce type C, D, $\mathrm{C} / \mathrm{D}$ and $\mathrm{D} / \mathrm{C}$ toxins, which are responsible for animal botulism outbreaks.

\footnotetext{
${ }^{*}$ Correspondence: caroline.lemarechal@anses.fr

${ }^{1}$ ANSES, Laboratoire de Ploufragan-Plouzané, Unité Hygiène et Qualité des Produits Avicoles et Porcins, Université Bretagne-Loire, BP 53, 22440 Ploufragan, France

Full list of author information is available at the end of the article
}

Detection of C. botulinum in an outbreak context is key to identifying sources of contamination, to monitoring dissemination of the pathogen, or to validating cleaning and disinfection operations. Considering that no selective media are available, C. botulinum group III is detected using real-time polymerase chain reaction (PCR) after an enrichment step in anaerobic conditions. Molecular genotyping techniques, specifically PCR-based methods, are also commonly used to perform epidemiological investigations. Both approaches require good quality and yield deoxyribose nucleic acid (DNA). However, environmental samples such as dust, soil, and manure contain substances that can inhibit PCR or affect its efficiency. PCR inhibitors like humic substances, fulvic acids, polysaccharides, proteins, and organic compounds may be coextracted with DNA and affect downstream PCR application. Including a PCR inhibitor removal step 
to avoid these complications may therefore be necessary to obtain analyzable DNA.

Many studies have been conducted on various matrices to compare DNA extraction procedures, but most of them focus only on one matrix or one pathogen, and their efficiency in extracting DNA varied among these parameters. Extraction methods differed in their ability to recover bacterial DNA, indicating that no single DNA extraction method was optimal for all bacteria [3, 4]. Moreover, the Gram-positive, spore-forming nature of C. botulinum may introduce some challenges. DNA isolation from spores is considered time-consuming and arduous and sometimes uses harsh, potentially DNAdamaging chemical treatments or mechanical lysis protocols [5, 6]. An ideal commercial nucleic acid extraction kit for use with $C$. botulinum in environmental samples would provide efficient cell lysis from vegetative cells and spores, remove inhibitors and be strain-independent.

The aim of this study was to evaluate the detection of C. botulinum group III from various environmental samples by real time PCR using four different DNA extraction kits. The efficiency of extraction was evaluated using a C. botulinum group III-specific real-time PCR assay [7], which targeted bont genes. PCR inhibition was measured with a commercial real-time PCR inhibitor assay.

\section{Main text}

\section{Materials and methods}

\section{Sample collection and enrichment conditions}

This study included 82 samples collected from 14 different farms after a botulism outbreak ( 9 type C/D, 2 type D, 2 type D/C, 1 negative): 28 swabs, 25 boot swabs, 3 water pipe swabs, as well as 5 water, 1 darkling beetles, 2 fly, 1 silage, 9 manure, and 8 soil samples. Outbreaks were reported by veterinarians and farm selection was based on the owners agreeing to take part in the study.

Test samples were collected and analyzed, and contained a minimum of $20 \mathrm{~g}$ for soil, manure, silage, and at least $100 \mathrm{~mL}$ for water, and also 10-15 darkling beetles or flies. Whole samples of manure, soil and silage were half diluted in pre-reduced trypticase-peptone-glucose-yeast extract broth (TPGY), manually homogenized, and $50 \mathrm{~g}$ of this diluted solution was diluted five times, according to the recommendations of Standard NF EN ISO 68876. Water was semi-diluted in two fold concentrated prereduced TPGY. Swabs and boot swabs were immersed in $250 \mathrm{~mL}$ pre-reduced TPGY. The ends of piping swabs were prepared for testing and placed into $9 \mathrm{~mL}$ of prereduced TPGY. Flies and darkling beetles were crushed and ten fold diluted in pre-reduced TPGY. They were then homogenized for $15 \mathrm{~s}$ using a Pulsifier ${ }^{\circledR}$ (Microgen Bioproducts, Camberley, United Kingdom). Incubation was performed at $37{ }^{\circ} \mathrm{C}$ for at least 4 days using an anaerobic chamber (Don Whitley A35, Bruz, France). After incubation, aliquots of $1 \mathrm{~mL}$ of each enrichment broth were prepared and stored at a temperature below $-18^{\circ} \mathrm{C}$ until DNA extraction.

\section{Kit selection and DNA extraction}

DNA extraction was performed using four commercial kits, following the manufacturers' instructions. The kits, using silica spin filter technology, were chosen for their easy and fast extraction methods. The following kits were evaluated: PowerSoil ${ }^{\circledR}$ DNA isolation kit (Mo Bio Laboratories Inc., Carlsbad, CA, USA), QIAamp ${ }^{\circledR}$ Fast DNA Stool Mini Kit and QIAamp ${ }^{\circledR}$ DNA Mini Kit (QIAGEN Inc., Valencia, CA, USA), and NucleoSpin ${ }^{\circledR}$ Soil (Macherey-Nagel, Duren, Germany). For NucleoSpin ${ }^{\circledR}$ Soil, sample lysis was performed with the optional enhancer SX solution and SL1 buffer. In the remainder of this article, the four kits are referred to as PS, QF, QA, and NS, respectively.

Aliquots from the same sample enrichment, stored at $-18{ }^{\circ} \mathrm{C}$, were tested. Enriched samples were stored from a few days (up to 3 days) to several months (up to 12 months). Extraction with the different kits was performed after a similar storage duration; variation in storage was only included for comparison within one kit. The sample enrichments were used for DNA extraction in duplicate using each kit.

\section{Real-time $P C R$}

The real-time PCR technique, and the primers and probes used in this study were described previously $[7,8]$.

\section{Statistical analysis}

The effect of storage time (long (up to 12 months) versus short (up to 3 days)) of enriched broth at a temperature below $-18{ }^{\circ} \mathrm{C}$ before DNA extraction on C. botulinum detectability was compared using a Wilcoxon test for paired samples with the software $R$.

\section{Results \\ Removal of PCR inhibitors}

The internal control was not detected in 14 DNA extracts when using the QA kit (Fig. 1), while the other kits enabled internal control amplification. Ten fold dilution of the DNA extracted using the QA kit allowed amplification of the internal control. More than half of the samples harboring PCR inhibitors when using QA were soils.

\section{Evaluation of C. botulinum detection using four different DNA extraction kits}

Results for bont gene detection are shown in Fig. 2. With the exception of manure, the PS had the best detection performance for all matrices (83.6\%). The other kits that 


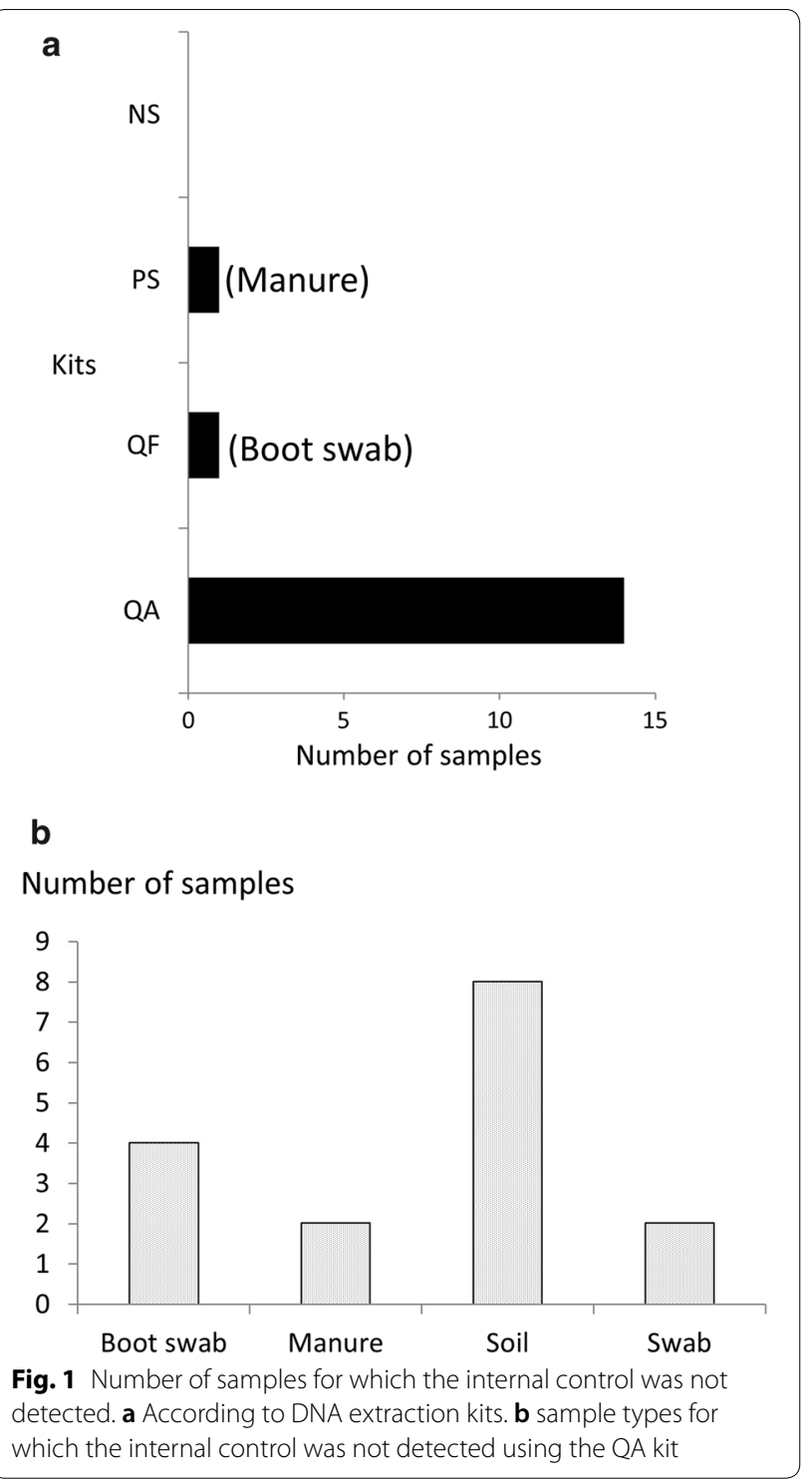

enabled detection of C. botulinum in $75.3 \%$ for NS, $68.5 \%$ for QA, and $45.2 \%$ for QF. Regarding detection of C. botulinum in manure, the NS gave the best detection results $(100 \%)$. PS enabled detection in only two samples of the nine tested, while the other two kits did not detect $C$. botulinum.

\section{Impact of long storage times of frozen enrichment aliquots on the efficiency of $C$. botulinum detection}

A significant positive effect of storage at $-18{ }^{\circ} \mathrm{C}$ on the efficiency of the extraction was observed $(p=0.002$ for CIII and 0.0098 for DII). A decrease in the Ct was indeed found after several months of storage of the enrichment at $-18{ }^{\circ} \mathrm{C}$ (Fig. 3).

\section{Discussion}

The aim of our study was to evaluate commercial DNA extraction kits for their ability to detect C. botulinum group III using real-time PCR for environmental samples. The effectiveness of molecular methods is strongly influenced by DNA extraction, which may affect the sensitivity of PCR-based methods for levels of DNA yield, purity, and integrity [9].

The presence of PCR inhibitors was determined using a commercial PCR inhibition assay. The use of a dedicated PCR as an inhibition control has previously been reported, and its comparison to DNA quality using absorbance ratios showed that it provides a more accurate indication of the presence of contaminants in the DNA extract [10].

The purity of extracted DNA was evaluated using a real-time PCR assay targeting the bont gene Here, DNA yield or quality were not used as criteria for kit evaluation given our specific objective of detecting one targeted pathogen using real-time PCR. Likewise, the measurement of DNA quantity with different kits would not have been informative regarding the efficiency of the kits to specifically extract C. botulinum DNA. The enrichment medium used in our study is in fact not selective and numerous bacterial species should have grown during the enrichment step. This type of analytical approach has previously been used successfully in other studies $[4,10]$.

Detection rate of $C$. botulinum group III varied among kits and matrices. This result showed the relevance of evaluating DNA extraction methods for each matrix, even for a single bacterial species. Results obtained with one DNA extraction kit for one matrix cannot be systematically extrapolated to all matrices. Similar differences between substrate types (soil and feces) or even subtypes (depending on the soil sample characteristics) and DNA extraction methods have previously been reported [10-12].

Only one soil sample was detected positive among all the samples tested (PS). This could be explained by the fact that coextracted charged organic compounds such as humic acids compete with nucleic acids for silica-binding sites, causing much of the nucleic acids to pass through. In addition, inhibitors present in the extract may also bind to the nucleic acids, preventing their retention on the silica filter [13]. Absence of amplification when using QA for soil DNA extraction might show that PCR inhibitors were not removed or were coextracted when using this kit.

The PS has been reported several times as being a good DNA extraction kit for different pathogens and matrices, either for DNA yield or for PCR inhibitor removal [11, $14,15]$. This seems to be consistent with our results.

The QF appeared to be the least appropriate for DNA extraction for C. botulinum detection in environmental 


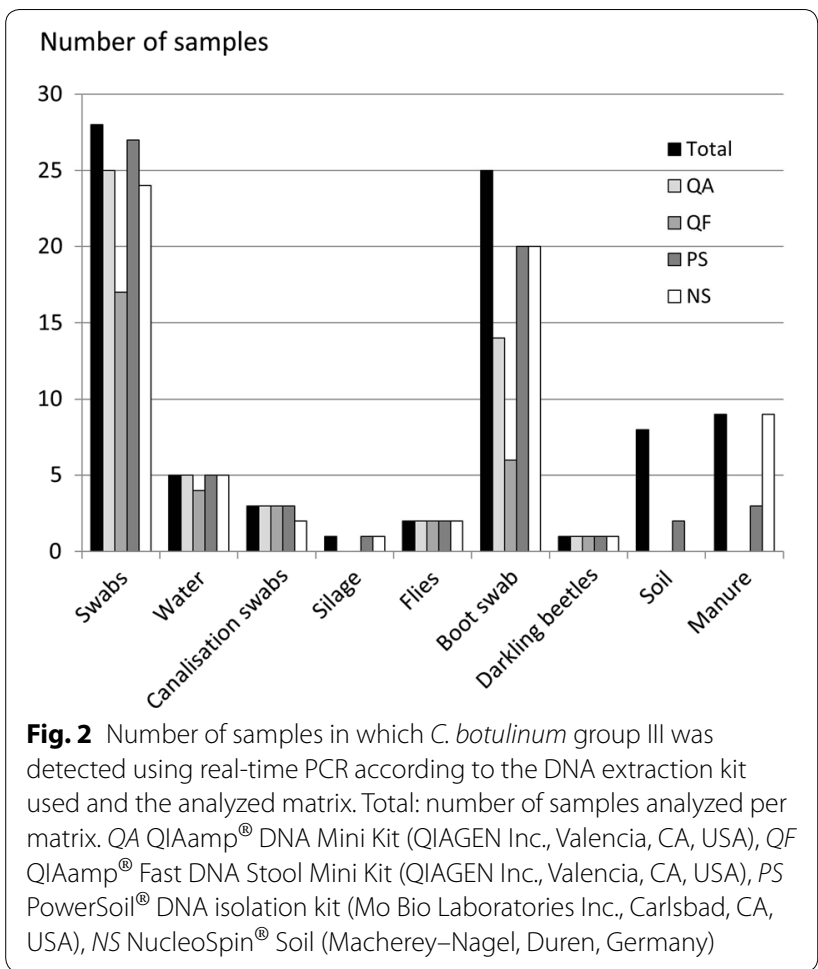

samples. Such results have already been reported for other pathogens, specifically in pig manure [12] or feces [4] when using the QIAamp DNA Stool Mini Kit. This could be explained by the absence of a mechanical disruption step, which is done with the PS and NS kits. Bead beating methods have been reported to be more efficient than chemical methods in detecting genes of various Gram-positive bacteria present in human fecal samples and sludge samples $[16,17]$. Surprisingly, QA gave better results than QF, although it is not recommended for complex samples. QA was previously shown to be the best extraction method for C. botulinum detection in various matrices when compared to three other methods [9].

NS was reported to be the best kit in another kit comparison study conducted on pig manure or lagoon effluent [12].

Long time storage of frozen enrichment aliquots significantly decreased the $\mathrm{Ct}$ in our study. Some other studies have suggested that freezing might slightly improve DNA extraction from selected Gram-positive bacteria [18]. It has also been shown that when expressing the bacterial data as relative abundance, the proportion of Clostridium in total bacteria was higher $(p<0.05)$ in frozen stored feces than in fresh feces [19].

\section{Conclusion}

The evaluation of four different commercial DNA extraction kits showed that the PowerSoil ${ }^{\circledR}$ DNA isolation kit was the most appropriate to extract DNA for the detection of C. botulinum group III in enriched

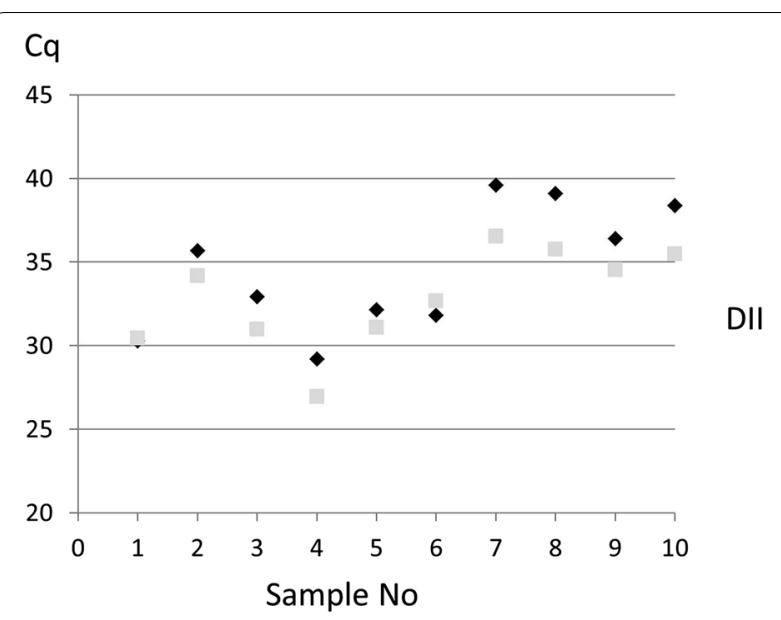

\section{$\mathrm{Cq}$}

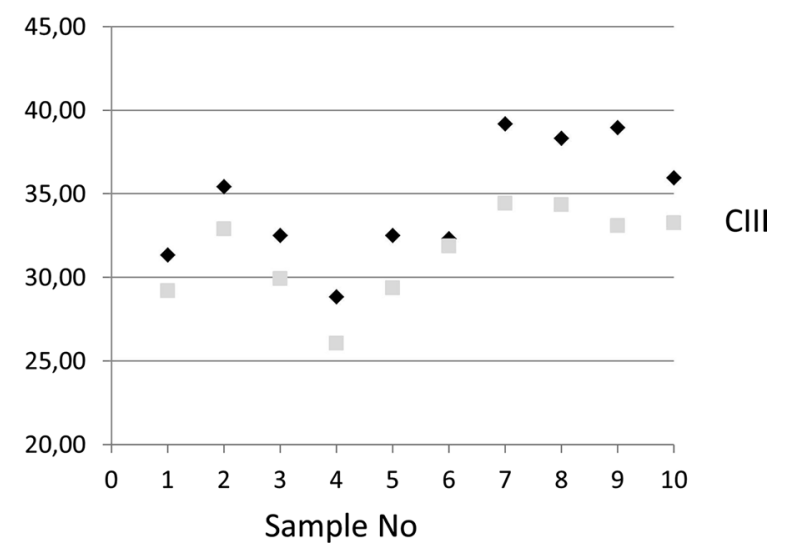

Fig. 3 Cq values obtained with different samples from one type D/C outbreak (positive for primers and probes CIII and DII) after short (black) or long (grey) storage of the enrichment at a temperature below $-18^{\circ} \mathrm{C}$

environmental samples, with the exception of manure samples for which the NucleoSpin ${ }^{\circledR}$ Soil kit yielded better results. In this study, we identified the appropriate kits for the detection of C. botulinum group III in environmental samples for various matrices. We also showed that long storage (several months) of enriched broth before DNA extraction improves the detectability of $C$. botulinum group III. This will be very helpful for epidemiological investigations and in understanding initial contamination during animal botulism outbreaks.

\section{Limitations}

Results obtained here are only valid for the detection of C. botulinum group III and the matrices tested here after enrichment of samples according to the conditions described in our study. The evaluation of the DNA extraction kits was only performed using naturally contaminated samples collected in botulism outbreaks context (with no 
information on the effective contamination or the amount of spores/bacteria in the samples) and not using spiking samples or using samples with a proved contamination, as commonly performed for DNA extraction kit comparison. Such evaluation should be performed again for other pathogens, other conditions of sample processing or a new matrix. The effect of long storage (several months) at a temperature below $-18{ }^{\circ} \mathrm{C}$ on the detection of C. botulinum group III was tested on a small number of samples. However the difference between short storage and long storage on the detection was significant and appeared so worth to be included in this article.

\section{Abbreviations \\ BoNT: botulinum neurotoxin; DNA: deoxyribose nucleic acid; NS: NucleoSpin ${ }^{\circledR}$ Soil (Macherey-Nagel, Duren, Germany); PCR: polymerase chain reaction; PS: PowerSoil ${ }^{\circledR}$ DNA isolation kit (Mo Bio Laboratories Inc., Carlsbad, CA, USA); QA: QIAamp ${ }^{\circledR}$ Fast DNA Stool Mini Kit; QF: QIAamp ${ }^{\circledR}$ DNA Mini Kit (QIAGEN Inc. Valencia, (A, USA).}

\section{Authors' contributions}

CLM, SF, VB and SR performed sample preparation, DNA extractions and PCR. RS collected the samples in farms. CLM and MC analyzed and interpreted obtained results. CLM, RS and MC wrote the manuscript. CLM acquired the funding for this study (BOTUNET project). MC is the general supervisor of the research group. All authors read and approved the final manuscript.

\section{Author details}

${ }^{1}$ ANSES, Laboratoire de Ploufragan-Plouzané, Unité Hygiène et Qualité des Produits Avicoles et Porcins, Université Bretagne-Loire, BP 53, 22440 Ploufragan, France. ${ }^{2}$ ANSES, Laboratoire de Ploufragan-Plouzané, Unité d'Épidémiologie et Bien-être en Aviculture et Cuniculture, Université BretagneLoire, BP 53, 22440 Ploufragan, France.

\section{Acknowledgements}

The authors are grateful to the poultry farmers and veterinarians who participated in this study.

\section{Competing interests}

The authors declare that they have no competing interests.

\section{Availability of data and materials}

The datasets generated and analyzed during the current study are available from the corresponding author on reasonable request.

\section{Consent for publication}

Not applicable.

\section{Ethics approval and consent to participate}

Not applicable.

\section{Funding}

This project was supported by France Agrimer (grant for the BOTUNET project 2013-2015), the French Agency for Food, Environmental and Occupational Health \& Safety (ANSES), the French Ministry of Agriculture, and the Côtes d'Armor Departmental Council. The funding bodies have no role in the design of the study and collection, analysis, and interpretation of data and in writing the manuscript.

\section{Publisher's Note}

Springer Nature remains neutral with regard to jurisdictional claims in published maps and institutional affiliations.
Received: 16 May 2018 Accepted: 27 June 2018

Published online: 04 July 2018

\section{References}

1. Skarin H, Tevell Åberg A, Woudstra C, Hansen T, Löfström C, Koene M, et al. The workshop on animal botulism in Europe. Biosecurity and Bioterrorism. 2013;11:S183-S90. http://www.scopus.com/inward/recor d. url?eid=2-s2.0-84883224586\&partnerlD $=40 \& \mathrm{md} 5=41 \mathrm{dad} 5$ fe8f989af afae271d484c2b318.

2. Ventujol A, Decors A, Le Maréchal C, Toux JY, Allain V, Mazuet C, et al. Le botulisme aviaire en France: Etude des cas signalés dans la faune sauvage et dans les élevages par deux réseaux de surveillance entre 2000 et 2013. Epidémiol Santé Animale. 2017;72:85-102.

3. Dauphin LA, Stephens KW, Eufinger SC, Bowen MD. Comparison of five commercial DNA extraction kits for the recovery of Yersinia pestis DNA from bacterial suspensions and spiked environmental samples. J Appl Microbiol. 2010;108:163-72. https://doi.org/10.111 1/j.1365-2672.2009.04404.x.

4. Whitehouse CA, Hottel HE. Comparison of five commercial DNA extraction kits for the recovery of Francisella tularensis DNA from spiked soil samples. Mol Cell Probes. 2007;21:92-6. https://doi.org/10.1016/j. mcp.2006.08.003.

5. Popham DL, Sengupta S, Setlow P. Heat, hydrogen peroxide, and UV resistance of Bacillus subtilis spores with increased core water content and with or without major DNA-binding proteins. Appl Environ Microbiol. 1995:61(10):3633-8.

6. Aslan K, Previte MJR, Zhang Y, Gallagher T, Baillie L, Geddes CD. Extraction and Detection of DNA from Bacillus anthracis Spores and the Vegetative Cells within 1 min. Anal Chem. 2008;80:4125-32. https://doi.org/10.1021/ ac800519r.

7. Woudstra C, Skarin H, Anniballi F, Fenicia L, Bano L, Drigo I, et al. Neurotoxin gene profiling of Clostridium botulinum types $C$ and $D$ native to different countries within Europe. Appl Environ Microbiol. 2012;78:3120-7. https://doi.org/10.1128/AEM.07568-11.

8. Souillard R, Le Marechal C, Ballan V, Mahe F, Chemaly M, Le Bouquin S. A bovine botulism outbreak associated with a suspected cross-contamination from a poultry farm. Vet Microbiol. 2017;208:212-6. https://doi. org/10.1016/j.vetmic.2017.07.022.

9. Auricchio B, Anniballi F, Fiore A, Skiby JE, De Medici D. Evaluation of DNA extraction methods suitable for PCR-based detection and genotyping of Clostridium botulinum. Biosecur Bioterror. 2013;11(Suppl 1):S200-6. https ://doi.org/10.1089/bsp.2012.0082.

10. Pontiroli A, Travis ER, Sweeney FP, Porter D, Gaze WH, Mason S, et al. Pathogen quantitation in complex matrices: a multi-operator comparison of DNA extraction methods with a novel assessment of PCR inhibition. PLoS ONE. 2011;6:e17916. https://doi.org/10.1371/journal.pone.0017916.

11. Dineen SM, Aranda R, Anders DL, Robertson JM. An evaluation of commercial DNA extraction kits for the isolation of bacterial spore DNA from soil. J Appl Microbiol. 2010;109:1886-96. https://doi.org/10.111 1/j.1365-2672.2010.04816.x.

12. Desneux J, Pourcher AM. Comparison of DNA extraction kits and modification of DNA elution procedure for the quantitation of subdominant bacteria from piggery effluents with real-time PCR. MicrobiologyOpen. 2014;3:437-45. https://doi.org/10.1002/mbo3.178.

13. Lloyd KG, MacGregor BJ, Teske A. Quantitative PCR methods for RNA and DNA in marine sediments: maximizing yield while overcoming inhibition. FEMS Microbiol Ecol. 2010;72:143-51. https://doi.org/10.111 1/j.1574-6941.2009.00827.x.

14. Pakpour S, Olishevska SV, Prasher SO, Milani AS, Chénier MR. DNA extraction method selection for agricultural soil using TOPSIS multiple criteria decision-making model. Am J Mol Biol. 2013;3:215-28.

15. Vojkovska H, Kubikova I, Kralik P. Evaluation of DNA extraction methods for PCR-based detection of Listeria monocytogenes from vegetables. Lett Appl Microbiol. 2015;60:265-72. https://doi.org/10.1111/lam.12367.

16. Guo F, Zhang T. Biases during DNA extraction of activated sludge samples revealed by high throughput sequencing. Appl Microbiol Biotechnol. 2013;97:4607-16. https://doi.org/10.1007/s00253-012-4244-4.

17. Salonen A, Nikkila J, Jalanka-Tuovinen J, Immonen O, Rajilic-Stojanovic $\mathrm{M}$, Kekkonen RA, et al. Comparative analysis of fecal DNA extraction 
methods with phylogenetic microarray: effective recovery of bacterial and archaeal DNA using mechanical cell lysis. J Microbiol Methods. 2010;81:127-34. https://doi.org/10.1016/j.mimet.2010.02.007.

18. Thomas V, Clark J, Dore J. Fecal microbiota analysis: an overview of sample collection methods and sequencing strategies. Future Microbiol. 2015;10:1485-504. https://doi.org/10.2217/fmb.15.87.
19. Metzler-Zebeli BU, Lawlor PG, Magowan E, Zebeli Q. Effect of freezing conditions on fecal bacterial composition in pigs. Animals. 2016;6:18.

Ready to submit your research? Choose BMC and benefit from:

- fast, convenient online submission

- thorough peer review by experienced researchers in your field

- rapid publication on acceptance

- support for research data, including large and complex data types

- gold Open Access which fosters wider collaboration and increased citations

- maximum visibility for your research: over $100 \mathrm{M}$ website views per year

At $\mathrm{BMC}$, research is always in progress.

Learn more biomedcentral.com/submissions 